(C) 1981. The Genetical Society of Great Britain

\title{
EFFECTS OF MIGRATION AND HABITAT CHOICE ON SHELL BANDING FREQUENCIES IN THEBA PISANA AT A HABITAT BOUNDARY
}

\author{
MICHAEL S. JOHNSON \\ Department of Zoology, University of Western Australia, Nedlands, \\ Western Australia 6009
}

Received 26.i.81

\begin{abstract}
SUMMARY
In a colony of the land snail Theba pisana the frequency of effectively unbanded shells is higher in exposed habitats than in adjacent thickets of Acacia bushes. Sampling over four years at a boundary between these habitats showed that the degree of association of morph frequencies with habitat varies seasonally and among years. Mark-recapture studies indicate that this variation results largely from a net movement of snails from the sheltered habitat during winter, and to the sheltered habitat for summer aestivation. Effectively unbanded individuals are less likely than fully banded individuals to move into the Acacia thicket for aestivation. This difference in habitat choice increases the difference in morph frequencies between sheltered and exposed habitats, and increases the probability of maintaining a stable polymorphism in a heterogeneous environment.
\end{abstract}

\section{INTRODUCTION}

OF all factors affecting the genetics of populations, migration is theoretically the simplest and empirically the least understood. On a local scale, gene flow between contrasting habitats could maintain genetic polymorphism, a possibility first treated theoretically by Levene (1953). The likelihood that selection in heterogeneous environments will result in stable polymorphism is greatly increased if different genotypes are able to choose the microhabitats in which they are most fit (Taylor, 1976; Powell and Taylor, 1979). Such habitat choice may well be common, since selection in heterogeneous environments should result in selection for attraction of each genotype towards the habitat in which it is favoured.

Evidence for differences in habitat choice among genotypes is now available for moths (Kettlewell, 1955; Boardman et al., 1974), mosquitoes (Coluzzi et al., 1977), Drosophila (Powell and Taylor, 1979; Cavener, 1979), isopods (Christensen, 1977), limpets (Giesel, 1970), and lizards (Schoener and Schoener, 1976). Polymorphic land snails would seem to provide excellent opportunities for the study of the effects of migration and habitat selection in heterogeneous environments, since associations of morph frequencies with habitat commonly occur over short distances. Surprisingly, no examples of such effects are cited in the extensive review of polymorphism in land snails by Clarke et al. (1979). The detailed study by Cain and Currey (1968) revealed no difference in movement between morphs of Cepaea nemoralis.

The Mediterranean snail Theba pisana (Müller) shows a close association of shell banding morphs and habitat in an introduced colony in 
Western Australia (Johnson, 1980). The large changes in morph frequencies observed over short distances imply either very strong selection, very limited gene flow, habitat choice, or combinations of these factors. The present study examines the effects of movements on spatial and temporal changes in morph frequencies in $T$. pisana at a habitat boundary.

\section{MAterials AND METHODS}

(i) Study area

The study site is in an area of coastal dunes at City Beach, Western Australia $\left(31^{\circ} 58^{\prime} \mathrm{S} ; 115^{\circ} 45^{\prime} \mathrm{E}\right)$. The area consists of a mosaic of thickets of Acacia bushes and areas of low, open vegetation, mainly grasses and Pelargonium. The proportions of effectively unbanded $T$. pisana average about 0.35 in the Acacia thickets and 0.65 in the open habitat, with changes between these values occurring over distances of $30 \mathrm{~m}$ (Johnson, 1980).

A transect $5 \mathrm{~m}$ wide and $65 \mathrm{~m}$ long was laid out across the boundary between the Open I and Acacia I areas of Johnson (1980). Within a distance of less than $10 \mathrm{~m}$ at this boundary, there is a change from Acacia bushes 1-3 $\mathrm{m}$ tall to grass and Pelargonium averaging about $20 \mathrm{~cm}$ in height (fig. 1). In the open vegetation there is a single Olearia axillaris bush about $2 \mathrm{~m}$ high and $2 \mathrm{~m}$ wide (within the segment W3 in fig. 1). The bushes

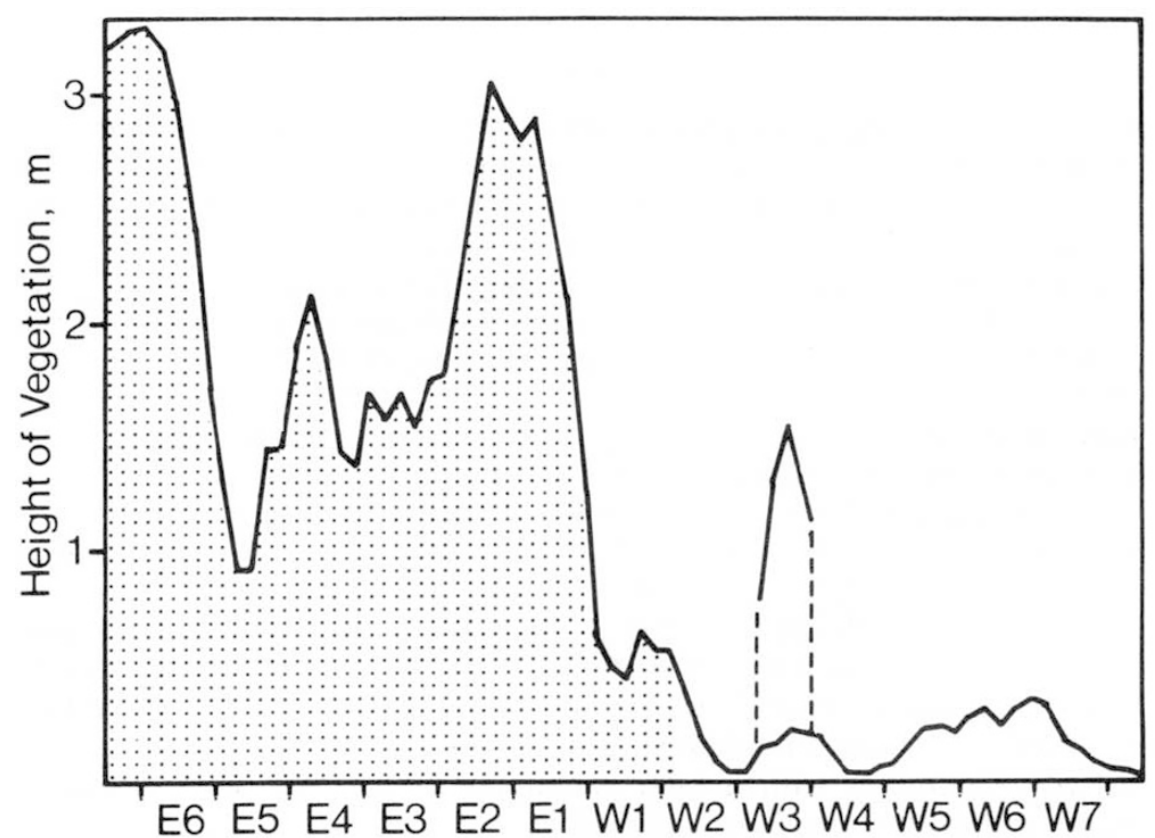

FIG. 1.-Maximum vegetation height along the transect at the habitat boundary. Values are moving averages over $3 \mathrm{~m}$ of measurements taken at each $1 \mathrm{~m}$ interval along the midline of the transect. Labelled segments along the axis are $5 \mathrm{~m}$ quadrats. Stippled portion indicates Acacia bushes, open portion grassy vegetation. Vertically displaced profile in W3 is the single Olearia bush. 
provide shade and aestivation sites 0.5 to $1.5 \mathrm{~m}$ off the ground, reducing the danger from high temperatures on the ground during summer (McQuaid et al., 1979).

\section{(ii) Sampling}

Ten times between July 1977 and November 1980 , adult ( $>10 \mathrm{~mm}$ ) T. pisana were collected from 13 contiguous $5 \times 5 \mathrm{~m}$ quadrats along the transect (quadrats labelled E6 to W7 in fig. 1). From November, 1978, onwards, snails from the single Olearia bush were kept separate from those in the surrounding grassy area of W3. At each sampling, a thorough search was made, in order to collect as many snails as possible from each quadrat. Since $T$. pisana remain above ground the entire year, the samples provide rough estimates of the actual numbers of adults present. At each sampling except the first, all animals were returned to their original quadrats.

During the summer months, $T$. pisana aestivate above the ground. They commence activity with the onset of winter rains in late April or May, and continue to be active until October or November. During each year of the study, collections were made in June or early July, at which time $T$. pisana are active and still laying eggs. In three of the four years, collections were also made in early November, by which time most $T$. pisana have chosen aestivation sites for the summer months. In two of the years, a further sampling was made in late February, towards the end of summer. An additional set of collections was made during a markrecapture experiment in August, 1980.

Each snail was scored as either effectively unbanded or fully banded, as described previously (Johnson, 1980). In lieu of extensive tables, morph frequencies and their standard errors are presented graphically. For each quadrat, the variance in morph frequencies throughout the study period was calculated. This variance includes sampling variance as well as variation due to real changes in morph frequencies over time. To obtain an estimate of the actual temporal component of the variance, the expected sampling variance was subtracted from the total variance. Sampling variance is a function of sample size, and the expected sampling variance was calculated as

$$
\sigma_{\text {sampling }}^{2}=\frac{\bar{p}(1-\bar{p})}{\bar{N}}
$$

where $\bar{p}$ is the average proportion of effectively unbanded shells, and $\bar{N}$ is the harmonic mean of the sample sizes for a particular quadrat (Crow and Kimura, 1970). Two samples with only single individuals were excluded from this analysis. The open portion of quadrat W3 was also excluded, because of an incomplete series of samples resulting from the inclusion of the Olearia bush in the early samples.

\section{(iii) Mark-recapture}

At each February and November sampling and in August, 1980, the snails were marked with dots of enamel paint on the underside of the shell, the snails from each quadrat being marked in situ with a different colour. Winter samples were taken to the laboratory for marking, and returned to 
their original quadrats within one week of capture. The purpose of the mark-recapture programme was to determine the extent of movement along the east-west transect, particularly between Acacia and open habitats. Since only those snails which remained on the $5 \mathrm{~m}$-wide transect were recaptured, the recaptures provide underestimates of the actual migration rates.

\section{RESULTS}

\section{(i) Spatial and temporal variation}

With the single exception of the June, 1978, samples, there is a higher proportion of effectively unbanded shells in the open habitat compared with the Acacia thicket (fig. 2). This close association with habitat is emphasized by the lower frequencies of effectively unbanded shells in the single Olearia bush than in the surrounding open areas of W3 and W4. Morph frequencies in this isolated sheltered habitat are the same as those in the Acacia area.
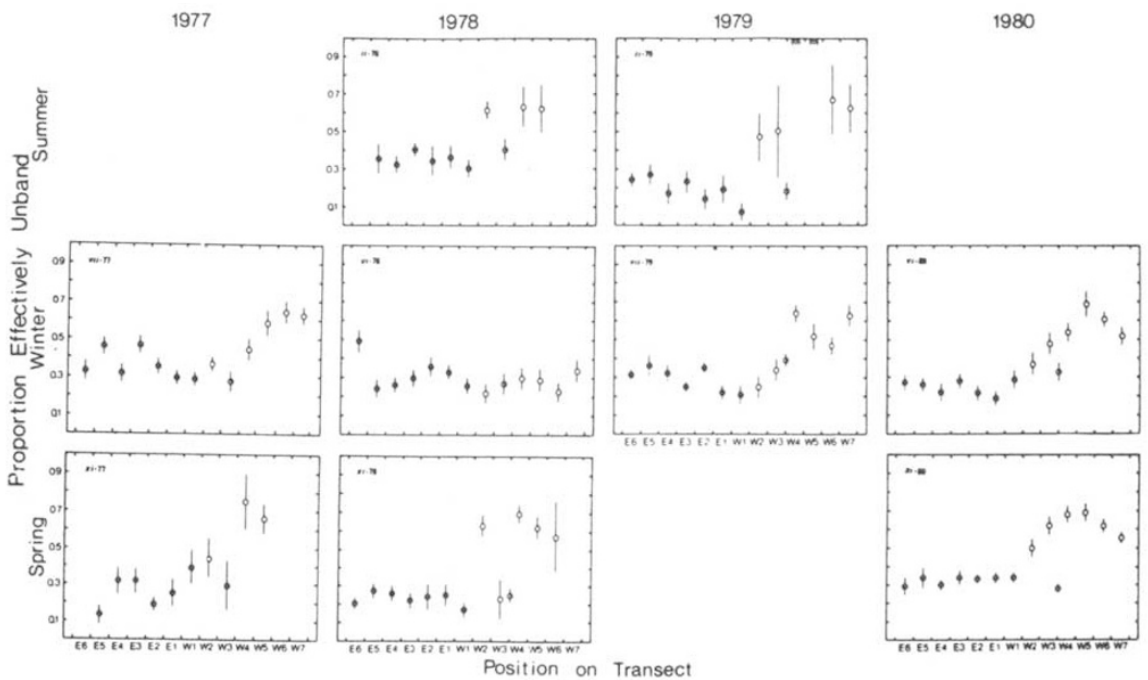

FIG. 2.-Proportions of effectively unbanded $T$. pisana in each quadrat on several sampling dates. Vertical lines indicate standard errors; bracketed values represent single individuals. Open circles indicate open habitat, solid circles Acacia habitat, and half-open the Olearia bush.

Superimposed on this spatial pattern is temporal variation in the distribution of morph frequencies, with both seasonal and year-to-year changes in the intensity of the association with habitat. In the winter samples of 1977,1979 , and 1980 , there were rather smooth clines, with the proportion of effectively unbanded shells increasing from about 0.3 in the Acacia area to about 0.6 in the open habitat, over distances of $15-20 \mathrm{~m}$. Interestingly, the morph frequencies are relatively constant throughout the Acacia, with the clinal variation occurring completely in the open area. 
In striking contrast with this pattern, there was no clinical variation in June, 1978. Instead, the proportion of effectively unbanded shells was about 0.3 in both habitats. This uniformity had developed within the four months since the February sampling. As surprising as this departure from the general trend was the rapid change back to high frequencies of effectively unbanded shells in the open habitat, with a return to proportions of about 0.6 within five months (fig. 2).

Although 1978 was unusual, it reflects a general seasonal pattern. In the spring samples of both 1978 and 1980, there is a clear step-cline in morph frequencies at the habitat boundary, contrasting with the smooth patterns in the winter samples. This step-cline is characteristic of the period of aestivation, as it is also clear in both sets of summer samples (fig. 2).

Most of the seasonal changes within individual quadrats are not statistically significant. However, the overall trend is clear if the directions of changes in morph frequencies are examined over the entire transect (fig. 3 ). Within the Acacia area, there was no consistent seasonal trend in the changes in morph frequencies. In the open vegetation, however, the proportion of effectively unbanded shells increased as the snails selected aestivation sites in the spring. Among all winter to spring comparisons for quadrats with open vegetation, one showed no change in morph frequencies, while the remaining twelve each showed an increase in the proportion of effectively unbanded shells $(P<0.001$, sign test $)$. No significant trends were evident for comparisons of spring and summer samples. However, of seven summer to winter comparisons, one showed no change, and six showed decreases in the proportion of effectively unbanded shells $(P<0 \cdot 05$, sign test). Thus, the uniformity of morph frequencies in the winter of 1978 , although unusual, is part of a general seasonal pattern in which the differences between Acacia and open habitats are most distinct during the dry season. Morph frequencies in the Olearia bush did not follow the seasonal pattern of those in the adjacent open vegetation.

A further pattern in the change in morph frequencies is clear when the temporal variation is calculated for each quadrat (fig. 4). As expected, the variance is consistently lower in the Acacia compared with that in the open $(P<0 \cdot 001, U$-test $)$. Again, the Olearia bush falls in with the Acacia rather than with the surrounding area of grass and Pelargonium. Among the open quadrats, however, the variance is greatest in W2, adjacent to the Acacia area, falling off along the transect to W7. Despite the small number of points, this negative correlation of variance with distance from the Acacia is statistically significant $(r=0.96, P<0.05)$.

In summary, the pattern to emerge is one in which morph frequencies change over very short distances in association with changes in habitat. Morph frequencies are relatively constant in the sheltered habitats, but vary seasonally in the exposed area, so that the association with habitat is strongest during the period of aestivation.

\section{(ii) Movements}

To determine whether changes in morph frequencies at the habitat boundary could be due to movements of the snails, movements of marked snails were studied. Aestivation sites are largely fixed by early November, with very little movement occurring between the November and February 


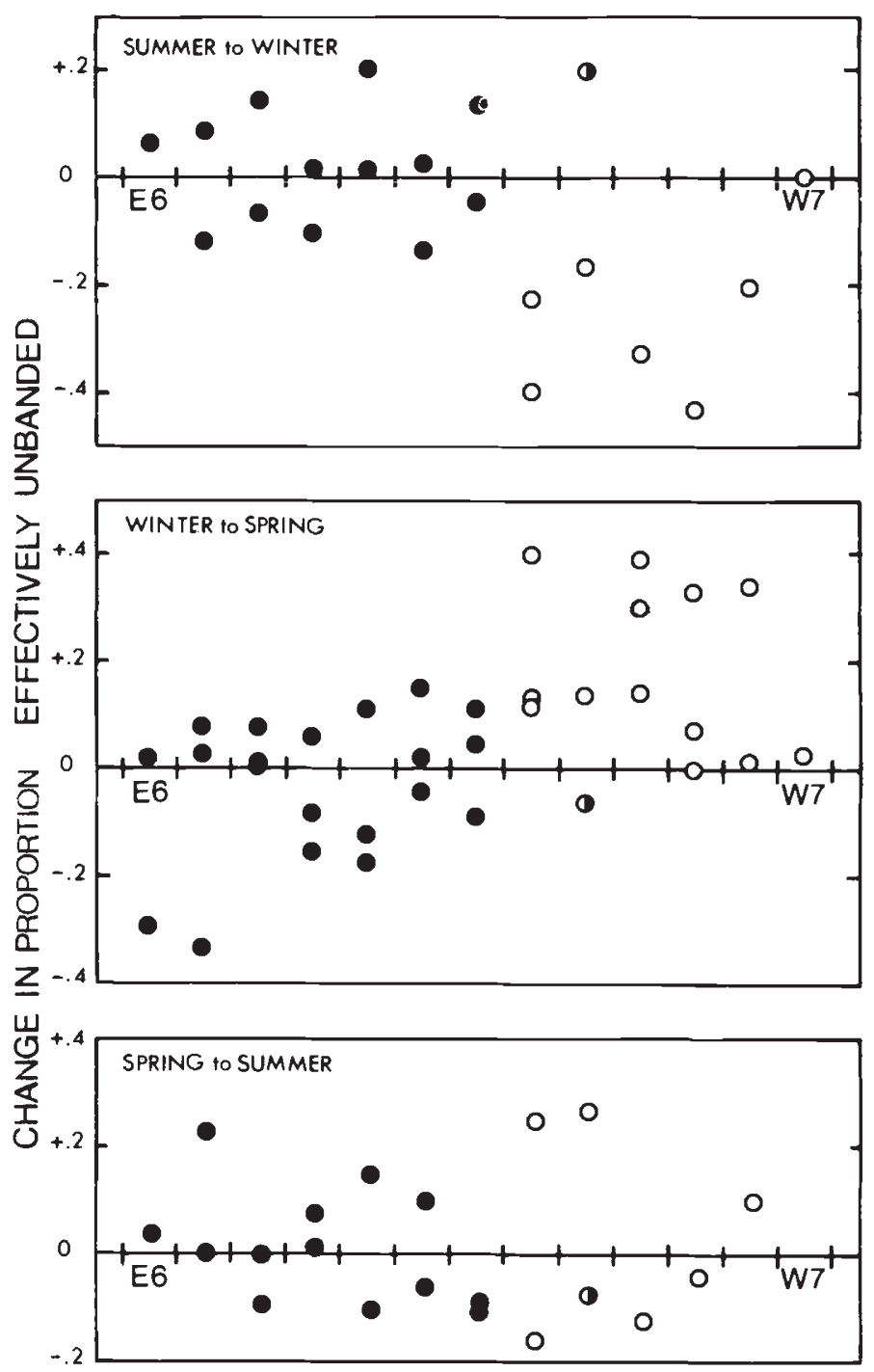

FIG. 3.-Changes in the proportion of effectively unbanded $T$. pisana between successive sampling dates in each quadrat of the transect. Symbols as in fig. 2 .

sampling dates (table 1). Combining the data from 1977-78 and 1978-79, the average east-west movement from spring to summer was only $1.1 \mathrm{~m}$ in the Acacia area and $0.3 \mathrm{~m}$ in the open vegetation.

With the onset of winter rains, movement increases considerably, although most individuals remain within $5 \mathrm{~m}$ of their original positions (table 1). Again combining the data for two years, average movement along the transect between the summer and winter sampling dates was $6.9 \mathrm{~m}$ and $7.3 \mathrm{~m}$ for snails marked in the Acacia and open areas, respectively. One 


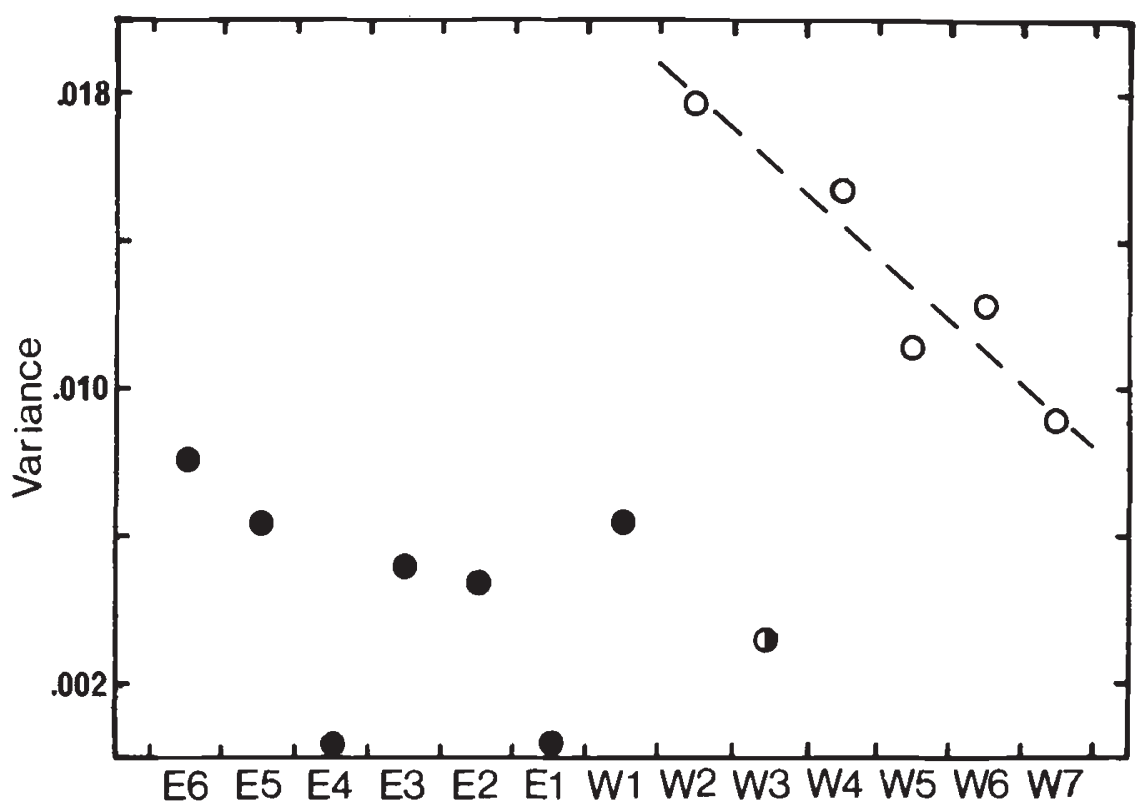

FIG. 4.-Variance over time in the proportion of effectively unbanded $T$. pisana in each quadrat. Symbols as in fig. 2. Dashed line is the regression line for quadrats in the open vegetation.

recaptured snail had moved $40 \mathrm{~m}$ along the transect, and several had moved $20 \mathrm{~m}$ or more.

Although distances travelled were similar in 1978 and 1979 , recoveries of snails were very different in the two summers. The summer of 1977-78 was considerably hotter and longer than any other during the study (table 2). Associated with this hot summer was heavy mortality of $T$. pisana, particularly in the open vegetation. Comparison of recaptures of living and dead shells confirms that 1) mortality was higher in both Acacia and

\section{TABLE 1}

Distances moved by marked $\mathrm{T}$. pisana during summer and early winter. Distances were determined in intervals of $5 \mathrm{~m}$ along the $5 \mathrm{~m}$-wide transect

\begin{tabular}{|c|c|c|c|c|c|c|c|c|}
\hline \multirow[b]{2}{*}{ Time/Habitat } & \multicolumn{7}{|c|}{ Distance (m) } & \multirow[b]{2}{*}{ Mean \pm S.E } \\
\hline & 0 & 5 & 10 & 15 & 20 & 25 & $\geq 30$ & \\
\hline \multicolumn{9}{|l|}{$\begin{array}{l}\text { November to } \\
\text { February }\end{array}$} \\
\hline 1977-78 Acacia & 13 & 6 & - & - & - & - & - & $1.58 \pm 1.38$ \\
\hline Open & 10 & 1 & - & - & - & - & - & $0.46 \pm 0.62$ \\
\hline 1978-79 Acacia & 116 & 30 & - & - & - & - & - & $1 \cdot 02 \pm 0.17$ \\
\hline Open & 26 & 1 & - & - & - & - & - & $0 \cdot 18 \pm 0.18$ \\
\hline \multicolumn{9}{|l|}{ February to July } \\
\hline \multirow[t]{2}{*}{1978} & 7 & 5 & 3 & 1 & 3 & - & 1 & $8 \cdot 50 \pm 2 \cdot 30$ \\
\hline & 1 & 1 & - & - & 1 & - & - & $8 \cdot 34 \pm 6 \cdot 01$ \\
\hline 1979 & 13 & 31 & 3 & 2 & 4 & 2 & - & $6 \cdot 28 \pm 0.86$ \\
\hline Open & 11 & 6 & 4 & 4 & 1 & 1 & - & $7.18+1.38$ \\
\hline
\end{tabular}


TABLE 2

Mean daily maximum temperatures $\left({ }^{\circ} \mathrm{C}\right)$ during summer months at Perth, Western Australia. Data from Australian Bureau of Meteorology

\begin{tabular}{lcccc} 
& \multicolumn{4}{c}{ Summer Season } \\
Month & $1976-77$ & $1977-78$ & $1978-79$ & $1979-80$ \\
November & $23 \cdot 2$ & $25 \cdot 5$ & $27 \cdot 0$ & $25 \cdot 0$ \\
December & $24 \cdot 6$ & $30 \cdot 7$ & $29 \cdot 0$ & $29 \cdot 3$ \\
January & $30 \cdot 4$ & $33 \cdot 3$ & $29 \cdot 8$ & $32 \cdot 1$ \\
February & $32 \cdot 1$ & $31 \cdot 9$ & $30 \cdot 6$ & $30 \cdot 5$ \\
March & $27 \cdot 2$ & $31 \cdot 8$ & $29 \cdot 2$ & $29 \cdot 8$ \\
April & 26.9 & $28 \cdot 2$ & $24 \cdot 2$ & $23 \cdot 1$
\end{tabular}

open areas in 1977-78 than in 1978-79, and 2) mortality was higher in the open area than in the Acacia (table 3).

\section{TABLE 3}

Comparison of proportions of dead individuals in summer samples of recaptured $\mathrm{T}$. pisana in Acacia and open habitats. Values are percent empty shells, with total numbers recaptured in parentheses. Probabilities are from

Fisher Exact Tests

$\begin{array}{lccc} & 1977-78 & 1978-79 & \text { Probability } \\ \text { Acacia } & 14 \%(22) & 1 \%(148) & 0.015 \\ \text { Open } & 52 \%(23) & 18 \%(33) & 0.008 \\ \text { Probability } & 0.007 & 0.006 & \end{array}$

The result of the massive mortality in 1977-78 was a paucity of $T$. pisana in the open by the end of summer. Of the 9 snails recaptured in the open area in June, 1978, 6 (67 per cent) had been marked in the Acacia area (table 4). In contrast, none of the 14 snails recaptured in the Acacia had been marked in the open, indicating a higher proportion of immigrants in the open area $(P=0.001$, Fisher Exact Test). This movement of snails from the Acacia to the open area following the onset of winter rains also occurred in 1979 (table 4), but the proportion of immigrants in the open area was 19 per cent, significantly lower than in $1978(P=0 \cdot 012$, Fisher Exact Test). Immigration into the Acacia from the open area was consistently low in both years (table 4).

In contrast with this westward movement during early winter, there was an eastward movement from winter to spring (table 4). Of 118 aestivating snails recaptured in the Acacia in November, 1980, 22 (19 per cent) had been marked in the open area the preceding August. Only 3 of 89 (3 per cent) recaptured snails in the open area had originated in the Acacia. Both the differences between habitats and the differences between seasons within habitats are highly significant $\left(P<0 \cdot 01, \mathrm{Chi}^{2}\right.$ or Fisher Exact tests).

Only with these winter to spring recaptures were sample sizes large enough to allow a test for differences between fully banded and effectively unbanded snails in their movements. Recapture rates did not differ significantly between the morphs. Consequently, the expected number of individuals of each morph marked in the open vegetation and recaptured 
TABLE 4

Movements of marked T. pisana between Acacia and open haultats. Statistical comparisons of immigration rates made with $\chi^{2}$ or Fisher Exact Tests

\begin{tabular}{ccccc}
\multicolumn{2}{c}{ Recapture } & \multicolumn{2}{c}{ Site of Release } \\
Season & Habitat & Acacia & Open & $\%$ Immigrants \\
Winter, 1978 & Acacia & 14 & 0 & $0 \%$ \\
& Open & 6 & 3 & $67 \%$ \\
Winter, 1979 & Acacia & 51 & 2 & $4 \%$ \\
Spring, 1980 & Open & 6 & 25 & $19 \%$ \\
& Acacia & 96 & 22 & $19 \%$ \\
& Open & 3 & 86 & $3 \%$
\end{tabular}

Comparisons of immigration rates

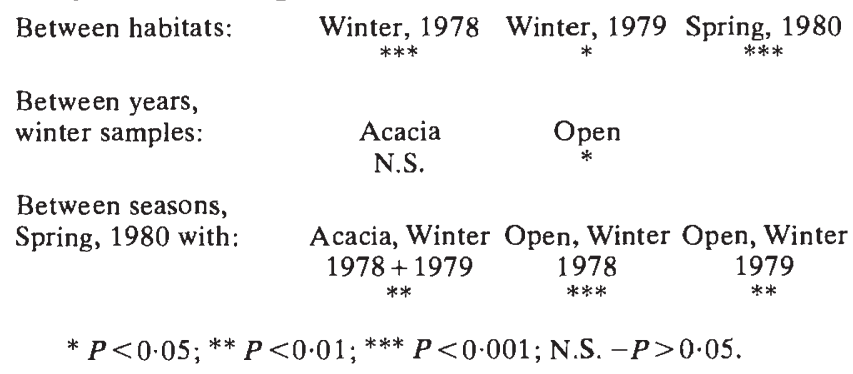

in the Acacia can be calculated from the morph frequencies in the source quadrats at the time of marking in August. Fewer than half as many effectively unbanded snails as expected moved into the Acacia for aestivation $(P<0 \cdot 05$; table 5$)$. The same trend is evident for movements from open vegetation to the Olearia bush (table 5 ), although numbers are too small for statistical testing. Thus the effectively unbanded individuals

\section{TABLE 5}

Numbers of marked T. pisana observed (and expected) to move from open vegetation ( $W 2$ to $W 7$, excluding Olearia bush) for aestivation in November, 1980. Expected values for each quadrat were calculated on the basis of morph frequencies in the quadrat in August 1980

\begin{tabular}{|c|c|c|c|c|}
\hline Area of Recapture & $\begin{array}{c}\text { Site of } \\
\text { Release }\end{array}$ & $\begin{array}{l}\text { Effectively } \\
\text { Unbanded }\end{array}$ & $\begin{array}{c}\text { Fully } \\
\text { Banded }\end{array}$ & $\chi_{1}^{2}$ \\
\hline Acacia & $\begin{array}{l}\text { W2 } \\
\text { W3 } \\
\text { W4 }\end{array}$ & $\begin{array}{l}3(6 \cdot 02) \\
0(0 \cdot 32) \\
0(0.98)\end{array}$ & $\begin{array}{r}11(7 \cdot 98) \\
1(0 \cdot 68) \\
2(1 \cdot 02)\end{array}$ & \\
\hline & Total & $3(7 \cdot 32)$ & $16(9 \cdot 68)$ & $4 \cdot 07^{*}$ \\
\hline Olearia & $\begin{array}{l}\text { W1 } \\
\text { W4 } \\
\text { W5 } \\
\text { W6 }\end{array}$ & $\begin{array}{l}0(0 \cdot 42) \\
1(1.47) \\
0(0.48) \\
0(0.40)\end{array}$ & $\begin{array}{l}1(0 \cdot 58) \\
2(1 \cdot 53) \\
1(0 \cdot 52) \\
1(0 \cdot 60)\end{array}$ & \\
\hline & Total & $1(2 \cdot 77)$ & $5(3 \cdot 23)$ & - \\
\hline Acacia or Olearia & Total & $4(10 \cdot 09)$ & $21(12 \cdot 91)$ & $6 \cdot 55^{*}$ \\
\hline
\end{tabular}

${ }^{*} P<0 \cdot 05$. 
moved into the sheltered habitats for aestivation less commonly than the fully banded individuals.

\section{Discussion}

The spatial variation of morph frequencies in $T$. pisana at the habitat boundary confirms on a finer scale the previously reported association of shell banding with habitat (Johnson, 1980). However, the pattern of variation at the boundary is dynamic. The temporal changes that stand out are:

(1) the major perturbation in 1978 , in which the association of morph frequencies with habitat was absent in the winter sample;

(2) the rapid return of high frequencies of effectively unbanded shells in the open habitat;

(3) the increase in the association of morph frequencies with habitat during the period of aestivation.

Natural selection presumably is the cause of the overall association of morph frequencies with habitat, which occurs on a scale of hundreds of metres (Johnson, 1980). The present study indicates, however, that the details of that association are determined largely by the movements of the snails. The first indication of a role of migration is the clinal variation in early winter, which occurs entirely within the open habitat, rather than across the abrupt habitat boundary. This asymmetry suggests a net flow of genes from the Acacia to the open area. Consistent with this suggestion is the greater abundance of $T$. pisana in the Acacia area, averaging 100 adult snails per $25 \mathrm{~m}^{2}$, compared with 66 in the open vegetation. Indeed by the end of summer, adult $T$. pisana may be absent from some quadrats in the open habitat.

The mark-recapture results document movement of $T$. pisana from the Acacia to the open area during early winter. The effect of this was most striking in 1978, following the very heavy mortality in the open area during the particularly long and hot summer of 1977-78. The subsequent immigration of snails into the open from the Acacia area produced low frequencies of effectively unbanded shells at distances up to at least $30 \mathrm{~m}$ from the sheltered habitat. A site in open dune vegetation $45 \mathrm{~m}$ from the Acacia area maintained high frequencies of effectively unbanded shells throughout the study period (unpublished data). Although the recoveries of empty marked shells do not provide estimates of actual mortality rates, they do confirm that mortality was greater during the summer of 1977-78 than in 1978-79. The winter sample in 1979 shows a correspondingly smaller impact of migration from the Acacia to the open area. Thus, the unusual uniformity of morph frequencies in June, 1978, is apparently an extreme manifestation of an annual combination of the effects of summer mortality and winter migration.

There are conflicting published estimates of rates of movement of $T$. pisana. In coastal dunes in South Africa, Hickson (1972) estimated an average movement of only $4.2 \mathrm{~m}$ per year. However, this was based on movements in isolated patches of vegetation during summer, and is undoubtedly an uncerestimate. On Rottnest Island, Western Australia, intro- 
duced colonies of $T$. pisana have spread through favourable habitat at an average rate of more than $20 \mathrm{~m}$ per year (Johnson and Black, 1979). Although this value would overestimate the effects of gene flow in a continuous population, it indicates the ability of $T$. pisana to fill available habitat, such as occurred in the open area following the hot summer of 1977-78.

Recaptures of marked snails in winter samples at City Beach indicate average movements of about $7 \mathrm{~m}$ along the transect over a period of about 4 months. This is an underestimate of actual movements, because individuals that moved off of the $5 \mathrm{~m}$-wide transect were not recaptured. In addition, these movements were of adults only, and any movement by juveniles would increase the flow of genes along the transect. Although differences in the direction of movement during winter and spring complicate analyses, it is clear that considerable movement occurs during the reproductive season. Even based on these crude data, the implication is that there is panmixia over distances of at least $20 \mathrm{~m}$ along the transect. This is consistent with estimates of neighbourhood sizes on the order of $30 \mathrm{~m}$ in Cepaea nemoralis and Helix aspersa (Lamotte, 1951; Selander and Kaufman, 1975). Any genetic heterogeneity within the panmictic unit must be established each generation.

If the spatial and seasonal variations in morph frequencies at the habitat boundary were due to selective mortality, the mortality rates required would be very large. For example, a change in the frequency of effectively unbanded shells from 30 per cent to 60 per cent, which can occur within $5 \mathrm{~m}$, would require the death of 50 per cent of the population, including more than 70 per cent of the fully banded snails. This is a minimal estimate, assuming entirely selective mortality, in which only fully banded individuals die. Similar mortality rates would be required to account for the dramatic return to high frequencies of effectively unbanded shells between June and November, 1978, during the most benign portion of the year. These unreasonably high selective mortality rates suggest that selection is not the cause of the fine-scale changes in morph frequencies.

A conceivable explanation of the return to high frequencies of effectively unbanded shells in the open area in November, 1978, is recruitment of predominantly effectively unbanded snails into the adult-sized population. Since $T$. pisana normally require two winters to mature (Avidov and Harpaz, 1969), such recruits would have been born in 1976 or 1977 , when effectively unbanded snails were more common in the open area. However, samples in 1980 showed no effect of the high proportion of fully banded adults in the open area during the reproductive season of 1978 . Consequently, the effects of recruitment are an unlikely explanation of the major features of temporal variation.

Rather, annual migration is apparently the main determinant of morph frequencies near the habitat boundary. The net movement of snails from the Acacia to the open area in early winter breaks down the step-cline apparent during the hot season. The reverse migration in the spring, when the snails choose aestivation sites, reestablishes the step-cline. The effects of these annual movements are greatest adjacent to the Acacia, as shown by the occurrence of the greatest variance in morph frequencies in quadrat W2. 
Habitat selection increases the differences in morph frequencies between habitats, as fully banded snails move preferentially from the open vegetation into the sheltered habitat for aestivation. This habitat preference accounts for the absence of an increase in the proportion of effectively unbanded shells in the Acacia and Olearia bushes at the end of winter. Unfortunately, the data were inadequate to test for habitat selection during early winter. In addition, the aestivation sites during 1979-80 of the aestivating snails recaptured in the spring of 1980 were not known. Consequently, it is possible that the observed habitat selection results from a genetically random annual migration between aestivation sites in the Acacia bushes and winter feeding sites in the open vegetation. That is, differences in habitat choice could be between snails from different areas which happen to differ in morph frequencies, rather than between banded and effectively unbanded snails as such. It will be necessary to determine the movements of individual snails through an entire year to distinguish between these alternatives.

In either case, the habitat selection helps to maintain the close association of shell banding morphs and habitat. Although natural selection among banding types in $T$. pisana has not been demonstrated, its existence must be assumed in order to account for the association of morph frequencies and habitat along a $600 \mathrm{~m}$ transect at City Beach (Johnson, 1980) and an increase in the proportion of effectively unbanded shells in warmer, drier areas of Israel (Nevo and Bar, 1976). Habitat selection presumably reduces the effects of this natural selection, as each morph tends to choose the habitat in which it will be most successful.

There has been considerable recent interest in the maintenance of genetic polymorphism through contrasting selection among habitats. In the absence of habitat choice, however, the requirements for stable polymorphism by such selection are very stringent (Maynard Smith and Hoekstra, 1980). This study of $T$. pisana adds to a growing list of examples of habitat choice which increases the likelihood that environmental heterogeneity plays an important role in the maintenance of genetic polymorphism. The fact that morph frequencies in the single Olearia bush in the open area behave in all important respects as those in the Acacia area emphasizes that the scale of that heterogeneity need not be large.

Acknowledgements.-I thank A. Boulton, L. Collins, L. Craven, J. Dolva, P. Middleton, and J. Turner for assistance, and D. J. Ayre and J. D. Roberts for comments.

\section{REFERENCES}

AVIDOV, Z., AND haRPAZ, I. 1969. Plant Pests of Israel. Israel Universities Press, Jerusalem. BOARDMAN, M., ASKEW, R. R., AND COOK, L. M. 1974. Experiments on resting site selection by nocturnal moths. J. Zool., Lond., 172, 343-355.

CAIN, A. J., AND CURREY, J. D. 1968. Ecogenetics of a population of Cepaea nemoralis (L.) subject to strong area effects. Phil. Trans. Roy. Soc, B, 253, 447-482.

CAVEnER, D. 1979. Preference for ethanol in Drosophila melanogaster associated with the alcohol dehydrogenase polymorphism. Behav. Genet., 35, 45-57.

CHRISTENSEN, B. 1977. Habitat preference among amylase genotypes in Asellus aquaticus (Isopoda, Crustacea). Hereditas, 87, 21-26.

ClARKE, B., ARTHUR, W., HORSLEY, D. T., AND PARKIN, D. T. 1979. Genetic variation and natural selection in pulmonate molluscs. In Pulmonates, volume $2 \mathrm{~A}$, eds, V. Fretter and J. Peake, pp. 219-270. Academic Press, London. 
Coluzzi, M., SAbatini, A., Petrarcha, V., AND DideCo, M. A. 1977. Behavioural divergences between mosquitos with different inversion karyotypes in polymorphic populations of the Anopheles gambiae complex. Nature, 266, 832-833.

CROW, J. F., AND KIMURA, M. 1970. An Introduction to Population Genetics Theory. Harper \& Row, New York.

GIESEL, J. T. 1970. On the maintenance of a shell pattern and behaviour polymorphism in Acmaea digitalis, a limpet. Evolution, 24, 98-119.

HICKSON, T. G. L. 1972. A possible case of genetic drift in colonies of the land snail Theba pisana. Heredity, 29, 177-190.

JOHNSON, M. S. 1980. Association of shell banding and habitat in a colony of the land snail Theba pisana. Heredity, 45, 7-14.

JOHNSON, M. S. AND BLACK, R. 1979. The distribution of Theba pisana on Rottnest Island. West. Australian Natur., 24, 140-144.

KETTLEWELL, H. B. D. 1955. Recognition of appropriate backgrounds by the pale and black phases of Lepidoptera. Nature, 175, 943-944.

LAMOTTE, M. 1951. Recherches sur le structure génétique des populations naturelles de Cepaea nemoralis (L.). Bull. Biol. Fr. Belg. (Suppl.) 35, 1-239.

LEVENE, H. 1953. Genetic equilibrium when more than one niche is available. Am. Nat., 87, 331-333.

MAYNARD SMITH, J., AND HOEKSTRA, R. 1980. Polymorphism in a varied environment: how robust are the models? Genet. Res., Camb., 35, 45-57.

MCQUAID, C. D., BRANCH, G. M. AND FROST, P. 1979. Aestivation behaviour and thermal relations of the pulmonate Theba pisana in a semi-arid environment. Thermal Biology, 4, 47-55.

NEVO, E., AND BAR, Z. 1976. Natural selection of genetic polymorphisms along climatic gradients. In Population Genetics and Ecology, eds. S. Karlin and E. Nevo, pp. 159-184. Academic Press, New York.

POWELL, J. R., AND TAYLOR, C. E. 1979. Genetic variation in ecologically diverse environments. Am. Scientist, 67, 590-596.

SCHOENER, T. W. AND SCHOENER, A. 1976. The ecological context of female pattern polymorphism in the lizard Anolis sagrei. Evolution, 30, 650-658.

SELANDER, R. K. AND KAUFMAN, D. W. 1975. Genetic population structure and breeding systems. In Isozymes, volume IV, ed. C. L. Markert, pp. 27-48. Academic Press, New York.

TAYLOR, C. E. 1976. Genetic variation in heterogeneous environments. Genetics, 83, 887-894. 